\title{
PUBLIC ADMINISTRATION OF AGRICULTURAL LAND: CASE OF SAMARA REGION
}

\author{
Alexandr Vlasov ${ }^{1}$, Darya Vasilieva ${ }^{1}$, Velta Parsova ${ }^{2}$ \\ ${ }^{1}$ Samara State University of Economics, ${ }^{2}$ Latvia University of Life Sciences and Technology
}

\begin{abstract}
As result of land reform in Russian Federation the public administration of agricultural land has been totally transformed. Land reform was carried out in order to solve problems in the sphere of agriculture, housing construction, ecology, creating a plurality of land ownership forms, introducing land use payments, etc. The decision to cancel monopoly of state ownership in land and to create institution of private property was made. The land redistribution projects for each farm were made, where stock of shares, stock of land redistribution and stock of land administered by previous soviet village councils was represented.

The example of the Samara region was used to develop mechanisms for transfer of public land to private ownership. Currently, the situation with use of the land in many agricultural enterprises can be considered as unsatisfactory due to unsystematic economic activity - there are no or are not implemented scientifically based crop rotations, natural soil fertility is not taken into account, there is no modern cartographic material indicating the size of the fields, degree of slope and degree of erosion. Significant deterioration of the agro-ecological situation and the spread of negative processes on arable land require changes in national land policy and development of comprehensive measures to organize rational use of land. In the near future, a significant modernization of national and federal land legislation is planned, which will affect all subjects of the Russian Federation in terms of the management and use of agricultural land.
\end{abstract}

Key words: crop rotation, erosion, private property, public administration, soil fertility.

\section{Introduction}

Agricultural land has high importance for national food security. As result of land reform the total transformation of state administration over agricultural land was implemented. Land reform was carried out in order to solve problems in the sphere of agriculture, housing construction, ecology, creating a plurality of land ownership forms, introducing land use payments, etc. A large number of scientific publications are devoted to discussing the results of land reform in the field of state land management, especially about agricultural land category (Волков, Хлыстун, 2018; Volkov, Cherkashina, 2018; Khasaev, et.al., 2018; Кресникова, 2015; Дмитриева, et.al., 2015).

Since start of land reform the law "On land reform" and "On peasant (farmer) holdings" has been entered into force. Land Code and the Law on Land Payments, adopted in 1991, allowed the emergence of various forms of land ownership. As exception the right to private property referred to the land used for farming, because land was excluded from civilian circulation and moratorium on the purchase - sale of land for 10 years was introduced. Moratorium was canceled in 1992 in relation to land for gardening, individual housing construction and personal subsidiary farming. Further development of land reform was given by Decree of President of the Russian Federation No. 323 (27.12.1991) "On urgent measures for implementing land reform in the Russia", which provided the process of reorganization of larges agricultural enterprises and allotment of land shares to the employees of these enterprises. In accordance with the Decree of the President of the Russian Federation No. 1767 (10.27.1993) "On regulation of land relations and development of agrarian reform in Russia", the decision to abolish the monopoly of state ownership to land and emergence of the institution of private property was made. After that land redistribution projects for all farms were developed, in which were allocated:

- stock of shares in land (shares were given to employees of state and collective farms, as well as to employees of service holdings;

- $\quad$ stock of land redistribution (for internally displaced persons, military personnel, students, etc.);

- stock of land administered by previously existing village councils (land was used to expand the area of settlements, as well as for grazing livestock by settlements residents, etc.). 
The aim of the article is to study current condition of management problems of agricultural land at the regional level on the example of the Samara region. To achieve this goal, the following tasks were solved:

- analysis of current land stock condition in the region in general and, particulary, agricultural land;

- dynamics over last 10 years based on statistical reports on condition and use of land in Samara region and Russian Federation in general;

- identification of management of land stock mechanisms, of most acute problems;

- proposals for solutions of problems at regional and federal level.

In the process of implementing the reform on territory of Russia, the example of Samara region was used to develop mechanisms to transfer the land from state ownership to private ownership. One of the first regional law "On the land of the Samara Region" was adopted in studied region, which was tested at scientific and practical meetings in Germany and Austria. Significant part of this regional law was used in the development of the Land Code of the Russian Federation adopted in 2001. In 2000, under governance of the President of the Russian Federation in the Samara took place the meeting on agrarian issues. The government of Russia included the Samara region in the pilot projects of Laris and Tacis, which provided support for progress of land reform on land transfer to private ownership.

\section{Methodology of research and materials}

Annual reports on the situation and use of the land stock and agricultural land both of Russian Federation and Samara region over past 10 years have been analysed. There have been used an information given by Ministry of Agriculture of the Russian Federation and other authorities of national and regional level as well. Based on this analysis the dynamics of agricultural land category areas, as well as changes in the areas of some types of land use, e.g., arable land, fallow land, etc. have been showed. In the paper an authority of various ministries and departments on land management issues have been examined, current situation in the regulatory framework and directions of its modernization after approval of planned federal laws in field of agricultural land management have been analysed.

\section{Discussions and results}

Samara region is part of the Volga Federal District. Agricultural land category dominates (76\%) in the composition of the land stock of the region. This makes Samara region different from the land stock of the Russian Federation, where forest land category dominates (66\%) (Папцов, 2009; Власов, et.al., 2013).

Agricultural land generally is located outside of boundaries of settlements, it is allocated and intended for agricultural purposes. Agricultural land generally is used by agricultural enterprises, organizations for production of agricultural products, research and training purposes, by citizens - for peasant farming, personal subsidiary farms, horticulture, livestock farming, haymaking and cattle grazing. Agricultural land also includes:

- land of land redistribution stock which is created for the purpose of land redistribution for agricultural production, creation and expansion of peasant farms, personal subsidiary farms, gardening and other agricultural purposes;

- agricultural land plots located outside of settlements boundaries and assigned to rural administrations.

On 01.01.2018 agricultural land in Samara region occupied an area of 4.1 million hectares. To compare with 2016, area of this land category has decreased by 0.2 thousand hectares due to their transfer to enlargement of settlements. Total area of agricultural land in frame of agricultural land category is 3.8 million hectares or $93 \%$. Breakdown of total area of agricultural land is: arable land $70 \%$, fallow land - 3\%, orchards - 1\%, meadows - $1 \%$ and pastures - $19 \%$ (Воронин, et.al., 2014). Investigation of quantitative and qualitative dynamics of agricultural land area in the Samara region is given in the table 1 .

Land Code of the Russian Federation defines that agricultural land has priority in use and is the subject to special protection. So, over the past 10 years the following dynamics can be traced - area of agricultural land has been gradually decreased both generally in the Russian Federation and in Samara region. 
Table 1.

Dynamics of changes of the area of agricultural land

\begin{tabular}{|l|c|c|c|c|c|c|}
\hline \multicolumn{1}{|c|}{ Indicators } & $\mathbf{2 0 0 8}$ & $\mathbf{2 0 1 0}$ & $\mathbf{2 0 1 3}$ & $\mathbf{2 0 1 6}$ & $\mathbf{2 0 1 7}$ \\
\hline \multicolumn{4}{|c|}{ in Russian Federation, million hectares } \\
\hline Area of agricultural land & 402 & 393 & 386 & 384 & 383 \\
\hline Arable land in composition agricultural land & 115 & 115 & 115 & 116 & X \\
\hline Area of fallow land in composition of agricultural land & 4 & 4 & 4 & 4 & X \\
\hline \multicolumn{7}{|c|}{ in Samara region, thousand hectares } \\
\hline Area of agricultural land & 4106 & 4089 & 4070 & 4067 & 4067 \\
\hline Arable land in composition of agricultural land & 2915 & 2871 & 2858 & 2858 & 2858 \\
\hline Area of fallow land in composition of agricultural land & 57 & 95 & 105 & 104 & 103 \\
\hline
\end{tabular}

Source: own elaboration, using statistical data of annual reports

At the same time at federal level area of arable and fallow land has not been changed. Whereas in Samara region area of arable land decreased by 56 thousand hectares. Since 2008 the area of fallow land has noticeably increased, however since 2013 the area of arable land has slightly increased due to ploughing of small areas of fallow land (Fig. 1) (Воронин et.al., 2014).

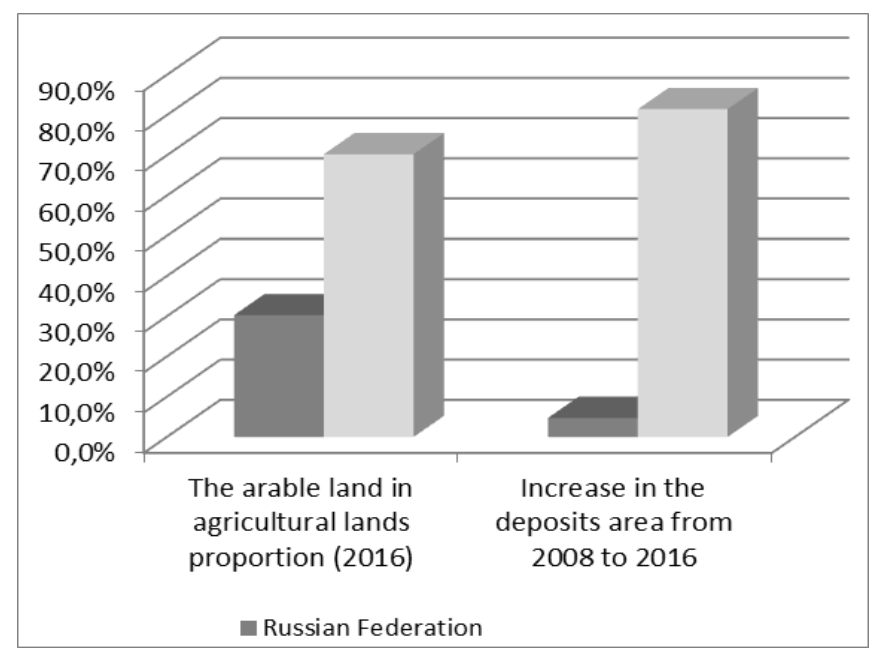

Fig.1. Comparison of breakdown of arable land and fallow land in Russian Federation and Samara region

On the territory of Russian Federation the agrochemical and ecological toxicological indicators in the soil, as well as changes in the structure of soil cover and the development of negative processes are monitored. These activities are carried out by federal state institution "Center and stations of the agrochemical service" and "Centers of agricultural radiology", which are subordinate to Ministry of Agriculture of the Russian Federation. Monitoring of soil cover and soil fertility indicators is carried out at intervals of $5-12$ years, annually covering only 8-10\% of agricultural land of the Russian Federation (Государственный (национальный) доклад ..., 2018). Results do not fully reflect the real situation (Доклад о состоянии ..., 2018). There is going on development of negative processes on agricultural land: wind and water erosion, salinization, rise of groundwater level, etc.

Wind erosion (deflation) is the most susceptible to arable land soil in Volga Federal District. Results of the survey in 2016 showed that 469 thousand hectares or $33 \%$ of the total area in Russian Federation were identified as exposed to wind erosion. Water erosion is widespread in all regions of the Russian Federation, but the largest areas are identified in Volga Federal District. According to the monitoring data in 2016 was identified salinization of soil on the territory of $3 \%$ of total arable land surveyed in Russian Federation. The largest area of saline land was identified in North Caucasus Federal District. Areas of wetland soils were identified on territory of $4 \%$ of total arable land surveyed 
in 2016, mainly such land is located in North-West Federal District. It should be noted that the cultivated area in Russian Federation has decreased from 118 million hectares in 1990 to 80 million hectares in 2016. At the same time yield of main crops, for example, grain and leguminous crops, increased from 19 (in 1990) to 26 (in 2016) cent./ hectare (Государственный (национальный) доклад ..., 2018).

On the territory of the Samara region last soil survey of fertility indicators of agricultural land was carried out in 2002 - 2004 for the purpose of statistics, and so far data from this survey are available, although they are undoubtedly outdated. For the period between survey in 1991 - 1992 and survey in 2002 - 2003 on agricultural land were identified negative processes as follows - content of humus on average decreased by $0.2 \%$, annual loss of humus was $0.4 \mathrm{t} /$ ha. Area of moderate humus soils decreased by $2 \%$ and area of low-humus and weakly humus soils increased accordingly by $0.3 \%$ and $1.4 \%$. Area of agricultural land exposed to water erosion and wind erosion has not changed. Area of wetland and swampy agricultural land increased by $0.3 \%$ due to flooding and rise in the level of groundwater. The area of re-saline soils decreased due to reduction in the area of irrigated land (Воронин et.al., 2014).

Problems of state management of the land stock, including the category of agricultural land, currently are related to the fact that in the Russian Federation there is no single authority for managing the land resources. Authorities are distributed between following authorities:

- Federal State Service of registration, cadastre and cartography (Rosreestr);

- Federal Service for Supervision of Natural Resources Management (Rosprirodnadzor);

- Federal Service for Veterinary and Phytosanitary Surveillance (Rosselkhoznadzor);

- Federal Agency for Use of Entrails of the Earth (Rosnedra).

Rosreestr performs the functions of state registration of rights to real estate and transactions with it, state cadastral real estate registration, land management, state land monitoring, geodesy and cartography, navigation support for the transport complex, state cadastral valuation, etc. By 2017 Cadastral Chamber fulfilled duties in the field of cadastral registration, formation and storage of State Real Estate Cadastre documents, registration of real estate ownership rights and transactions with them, as well as issues of cadastral valuation and inventory of all real estate objects - structures, buildings, premises, etc. Since2017 functions of cadastral registration and registration of rights are concentrated in the Rosreestr. An important issue now is the execution of work on the preparation of documents describing location of the boundaries of zones with:

- special conditions for use of territories;

- territories of cultural heritage objects;

- territories of advanced socio-economic development;

- zones of territorial development;

- gambling zones;

- forest areas and forest parks;

- especially protected natural territories;

- special economic zones;

- hunting grounds, etc.

Since 2017 in state cadastral evaluation should be involved specially created state budgetary institutions, which also should be responsible for disputing of cadastral value of real estate objects. In Samara region such an institution was established in end of 2018.

Rosprirodnadzor is subordinate to Ministry of Natural Resources and Ecology and performs the functions:

- control of land recultivation after completion of mining of mineral deposits;

- implementation of measures to improve land quality and protect the soil from wind and water erosion.

Rosselkhoznadzor is subordinate to Ministry of Agriculture. On agricultural land it carries out control over implementation of measures on:

- conservation and reproduction of fertility of agricultural land soil, including reclaimed land;

- fulfillment of requirements for prevention of unauthorized removal, movement and destruction of fertile soil layer; 
- damage to land as a result of violation of the rules for handling pesticides, agrochemicals or other substances hazardous to human health and the environment, as well as production and consumption of waste.

Rosnedra is subordinate to the Ministry of Natural Resources and Ecology, it performs the functions on:

- issue and registration of licenses for use of the entrails of the earth;

- issue of conclusions about absence of entrails of the earth under building sites of the upcoming construction;

- issue of permissions for construction of buildings on building sites with entrails of the earth under them.

So, in Russian Federation rights in land management are dispersed across different authorities ministries and departments, which lead to reduced responsibility for effectiveness of land use and protection.

Currently, the state of land in greatest part of agricultural enterprises of Samara region can be considered as not quite satisfactory due to unsystematic economic activity. They do not apply scientifically based crop rotations, placing crops in an agrolandscape is carried out without taking into account the natural fertility of the soil, there is no modern cartographic material indicating the size of the fields, slope steepness and level of eroded areas. Dominance of grain crops and sunflowers in cornfields with an insignificant application of mineral fertilizers reduces the nutrient reserves in the soil. Therefore significant deterioration of agro-ecological state and the spread of negative processes on arable land require the changes in national land policy and the development of comprehensive measures to organize the rational use of land by agricultural enterprises.

It is planned that in $201-2020$ in Russian Federation significant modernization of federal legislation relating to land issues will be implemented. These changes will affect all subjects of the Russian Federation in terms of the management and use of agricultural land. Because this category of land prevails in Samara region, changes in federal legislation will have significant consequences. One of the most significant purposes is the abolition of land categories. Taking into account the presence of great number of natural monopolies - gas and oil production companies, oil refining companies, main pipelines, etc., abolition of land categories will affect the region to a large extent, especially in terms of agricultural land the protection and rational use of agricultural land.

\section{Conclusions and proposals}

In 2018 in the Russian Federation has been adopted the legislative act "On approval of the plan of measures to improve the legal regulation of land relations". Author's consideration is that most important it is to adopt on the federal level legislative acts, providing:

- protection against unwarranted and/ or unreasonable changes of permitted use of the land plot;

- transition from land categories to territorial zoning;

- allocation of especially valuable agricultural land to the separate territorial zone, as well as establishment of criteria for assignment to such land;

- restriction of placement on agricultural land of objects not related to agricultural production;

- improvement of the system of inventory of agricultural land;

- adjustment of requirements of land management activities.

On the regional level it is necessary to carry out:

- reclamation, including cultural engineering activities associated with involvement of degraded and disturbed land in use;

- organization of full inventory of land and sustainable monitoring of land use;

- monitoring of law enforcement practice of federal laws in the field of land relations. 


\section{References}

1. Khasaev G., Vlasov A., Vasilieva D., Parsova V. (2018) Trends of development of agrolandscapes in Samara region as result of land reform. Proceedings of 17 th International Scientific Conference "Engineering for Rural Development". pp. 630-634.

2. Volkov C.H., Cherkashina E.V. (2018) Transfer into use of unused agricultural lands: significance, challenges, solutions. International Agricultural Journal. Volume 61. № 4. p. 4.

3. Власов А.Г., Воронин В.В., Васильева Д.И. (2013) Структура и оценка качества земель Самарской области (Structure and assessment of the quality of lands in the Samara region). Проблемы региональной экологии, №4. 2013. с. 109-116. (in Russian)

4. Волков С.Н., Хлыстун В.Н. (2018) Актуализация системы управления земельными ресурсами агропромышленного комплекса (Updating the land management system of the agro-industrial complex. Международный сельскохозяйственный журнал № 6 (366). с. 5-7 (in Russian)

5. Государственный (национальный) доклад о состоянии и использовании земель в Российской Федерации в 2017 году (2018) (State (national) report on the state and use of land in the Russian Federation in 2017), Федеральная служба государственной регистрации, кадастра и картографии. Москва, 197 с. (in Russian)

6. Дмитриева О.А., Кайдалова О.С., Кармолицкая Л.А. (2015) Практика управления и распоряжения государственными землями сельскохозяйственного назначения в Белгородской области (Practice of management and disposal of state agricultural lands in the Belgorod region). Труды Международной научно-практической конференции „Аграрная политика России в условиях международной и региональной интеграции", с. 124-129 (in Russian)

7. Доклад о состоянии и использовании земель в Самарской области в 2017 г. (2018) (Report on the state and use of land in the Samara region in 2017). Управление Федеральной службы государственной регистрации, кадастра и картографии по Самарской области, Самара (in Russian)

8. Доклад о состоянии и использовании земель сельскохозяйственного назначения Российской Федерации в 2016 году (2018) (Report on the status and use of agricultural land in 2016) - Москва, ФГБНУ "Росинфорагротех". 240 с. (in Russian)

9. Воронин В.В., Власов А.Г., Васильева Д.И. Мост Е.С. (2014) Опорный каркас развития территории (The basic framework of territorial development). Экология урбанизированных территорий №2, с. 41-49.

10. Кресникова Н.И. (2015) Государственное управление в сфере использования земель сельскохозяйственного назначения России (State administration in the use of agricultural land in Russia) Управленческие науки № 4. с. 42-51 (in Russian)

11. Кресникова Н. И. (2014) Разработка регламентов сельскохозяйственного землепользования (Development of regulations for agricultural land use). АПК: экономика, управление № 7. с. 28-34 (in Russian)

12. Папцов А. (2009) Правовое обеспечение землепользования в сельском хозяйстве развитых стран (Legal support of land use in agriculture of developed countries) АПК: экономика, управление № 9. с. 8588 (in Russian)

13. Пашута А.О., Солодовникова М.П. (2015) Мониторинг земель сельскохозяйственного назначения как метод государственного управления земельными ресурсами (Monitoring of agricultural land as a method of state land management). Вестник Воронежского государственного аграрного университета № 3 (46). c. 245-252 (in Russian)

Information about authors:

Alexander Vlasov. PhD, Head of the Department of Land management and cadastre of Samara State University of Economics. Address: Russia, 443090, Samara, Soviet Army street 141, phone +7(937)799-08-86, e-mail: kafzik@yandex.ru

Darya Vasilieva. PhD, Associate Professor of the Department of Land management and cadastre of Samara State University of Economics. Address: Russia, 443090, Samara, Soviet Army street 141, phone +7(927)20030-78, e-mail: vasilievadi@mail.ru

Velta Parsova. Dr.oec., professor, Department of Land Management and Geodesy of Latvia University of Life Sciences and Technologies. Address: 19, Akademijas str., Jelgava, LV-3001, phone: +371 29118285, e-mail: velta@parsova.lv 